\title{
Frost heaves in the cold arid Leh-Ladakh region: observations on their morphological variability and patterns as indicators of pastureland degradation
}

\author{
P. C. Moharana ${ }^{1}$, M. S. Raghuvanshi ${ }^{2}$, R. K. Bhatt ${ }^{1}$, R. K. Goyal ${ }^{1}$, R. K. Singh ${ }^{1}$, \\ H. M. Meena ${ }^{1}$, Mahesh Kumar' ${ }^{1}$ and Stanzin Landol ${ }^{3}$ \\ ${ }^{1}$ ICAR-Central Arid Zone Research Institute, Jodhpur 342 003, India \\ ${ }^{2}$ ICAR-National Bureau of Soil Survey and Landuse Planning, Nagpur 440 033, India \\ ${ }^{3}$ ICAR-Central Arid Zone Research Institute, Regional Research Station, Leh, India
}

This study analysed frost heave lands in the cold arid Leh-Ladakh region of the Himalaya, India through semi-detail field survey and remote sensing. Most of these sites are highland grasslands occurring along the alluvial plains of rivers in the Leh and Nubra valleys. The study identified the occurrence of some unique frost heave patterns whose morphometry varied from simple, isolated to complex ones with elongated, coalesced and superimposed bedforms. These lands can be further subdivided into vegetated and degraded types. The degraded forms exhibited several cracks, dry, collapsed and slump structures. Invasion of Cirsium arvense over native grass species, soil salinity and feeding pressure by livestock have been identified as major land degradation factors. $C$. arvense has replaced the native vegetation on frost heaves and has allowed Carex species to grow, which is known to degrade and deplete the pasture ecology.

Keywords: Cold arid region, frost heaves, morphological variability and patterns, pastureland degradation.

FROST heaves are typical land features of cold arid regions. A 'heave' is often described as a winter-time uplift (swelling) or displacement of the ground surface in cold climates. This phenomenon leads to development of uneven roads, cracked foundations and also causes damage to infrastructure ${ }^{1}$. Similar to frost heaves, many other land features such as patterned grounds, pingoo, palsa and lithalsa have also been reported from peri-glacial environment in the Arctic, Antarctica, northern Canada, Alaska, Siberia and Iceland. All these surfaces have definite geometric forms. Palsas are typical forms of discontinuous permafrost regions commonly occurring in areas where the winters are long and snow cover tends to be thin $^{2,3}$. Pingos are dome-shaped mounds that are up to $50 \mathrm{~m}$ high, consisting of a good concentration of ice at

*For correspondence. (e-mail: pcmohorana45@gmail.com) the core and a layer of soil on the surface often having vegetation ${ }^{4}$. There are reports about Mars having patterned ground.

The process of heaving or soil water accumulating and then freezing is well documented ${ }^{2,5,6}$. Taber, discredited the assumption that frost heaves result due to expansion of freezing water, but stated that it is caused due to water supply that helps ice growth inside the soil. Due to the weight of overlaying soil, vertical growth of ice is restricted and ice lenses are formed which are capable of lifting soil. Beskow ${ }^{5}$ recognized few factors like type and size of soil particles, amount of water availability, rate of freezing and overburden pressure determining frost heaving. This process has a direct impact on the soil, as it tends to disturb the frost layer when ice lenses on the soil accumulate and protrude. During thawing, ice lenses increase the water pressure on the soil pore spaces that results in soil destabilization, thus enhancing the potential for mass movements. Frost heaves when uniform, have no adverse impacts on land quality, but unequal heaves may be destructive.

In India, cold arid regions are spread over $0.70 \mathrm{~m}$ ha mainly in the Himalayan ranges. About $11.4 \mathrm{~m}$ ha area in this sector is covered by grasslands ${ }^{7}$. Frost heaving as a process of land degradation has affected about 7428 ha in the Jammu and Kashmir region ${ }^{8}$. Here we present an inventory of occurrences of frost heaves and documentation on their variability in the cold arid Leh-Ladakh region of the Himalaya and the impact on pasturelands of this region.

\section{Study area}

The study area is part of Leh (Ladakh) region (geographical area, 45,110 sq. km) in the northernmost part of India lying between lat $32^{\circ}-36^{\circ} \mathrm{N}$ and long $75^{\circ}-80^{\circ} \mathrm{E}$. It is located at the western end of the Himalaya, flanked by Tibet in the east, Kargil in the west, China in the north and Himachal Pradesh in the south. River Indus, high 


\section{RESEARCH ARTICLES}

mountain ranges, elevated plateaus, fan surfaces and rocky gorges are important geomorphic features in the Leh region ${ }^{9}$. The elevation of observation sites in this study ranges from $2600 \mathrm{~m}$ to $5030 \mathrm{~m}$ amsl. Leh city is situated in a large valley of River Indus lying between two Himalayan ranges - Zanskar in the west and Ladakh in the east. Nimoo, Shey, Thikshey, Choglamsar, Ranbirpur, Nang and Chushot are the major towns in the Leh valley while Diskit, Hunder, Lakjung, Khalsar and Sumur are the important towns of Nubra valley located at $3100 \mathrm{~m}$ elevation north of Leh. Changthang, situated at an elevation of $4000 \mathrm{~m}$ amsl in the south of Leh is a highaltitude pastureland. This cold arid region is characterized by low atmospheric pressure (493 $\mathrm{mm} \mathrm{Hg}$ ), low partial pressure of oxygen, high wind velocity $\left(8-10 \mathrm{~km} \mathrm{~h}^{-1}\right)$, very low annual precipitation $(80-300 \mathrm{~mm})$, sub-zero temperature (up to $-40^{\circ} \mathrm{C}$ ) and intense sunlight ${ }^{10,11}$. Three months (December-February) witness subzero temperature, while rest of the winter months till April experience $0^{\circ} \mathrm{C}$ temperature. May to October is the cropping season. Much of the surface water is through snowmelt. Streams during summer flow for a few hours per day when ice melts helping in the growth of vegetation, including grasses, shrubs and trees. Despite such harsh climate and rocky/glaciated terrain, settlements are located at various elevations of hills and valleys. Sheep and goat-rearing is an important component of people's living, particularly for the nomadic tribes.

\section{Methodology}

Frost-heave sites were identified through field surveys carried out at different altitudes in Leh, Nubra, Durbok, Kharu and Nyoma administrative blocks (Figure 1). Area covered under frost-heave lands was mapped from the Indian Remote Sensing (IRS) LISS IV satellite imageries of 2017-18 with background information viewed on Google Earth images. Morphological parameters of frost heaves (length, width and height) were measured in the field. Soil samples were collected up to $15 \mathrm{~cm}$ depth in the profiles of frost heaves. Vegetation composition at each site and biomass of grass species were computed through detailed assessment in grids of $1 \mathrm{~m} \times 1 \mathrm{~m}$ size at several sites.

\section{Results}

\section{Identification and mapping of frost-heave lands}

Frost-heaving processes create a type of patterned surface that has typical undulating morphology. These lands have been found to occur near stream channels, riverside, stagnated water bodies and lakes. Such associations have helped identify the frost-heave features on the false colour composites (FCC) of IRS LISS IV satellite image which has a spatial resolution of $5.8 \mathrm{~m}$. Field surveys and ground truthing conducted in the Leh-Ladakh region from 2013 to 2017 helped match the identified frostheave sites and their mapping at Saboo, Stakmo, Tangtse-Changthang, Giya-Tso Kar and Sakti in Leh and Diskit-Hunder in Nubra valley (Figure 1). Table 1 summarizes the types, morphology and patterns of frost heaves at these locations.

\section{Soil characteristics of frost-heave sites}

Tables 2 and 3 present the physico-chemical characteristics of soils at Leh and Nubra valley. Analysis shows that the soils are loamy sand to sand, with sand content varying from $74 \%$ to $91 \%$. The silt and clay contents are comparatively high varying from $5 \%$ to $16 \%$ and $3 \%$ to $10 \%$ respectively, except in Tso Kar-Giya valley where silt content is $20.45 \%$. The higher silt and clay contents may be because of valley side location and deposition of alluvial soils formed by riverine deposits. Soils are alkaline with $\mathrm{pH}$ values ranging from 7.9 to 9.1. Sand dunes near Shey, Thikshey and Choglamsar towns indicate the

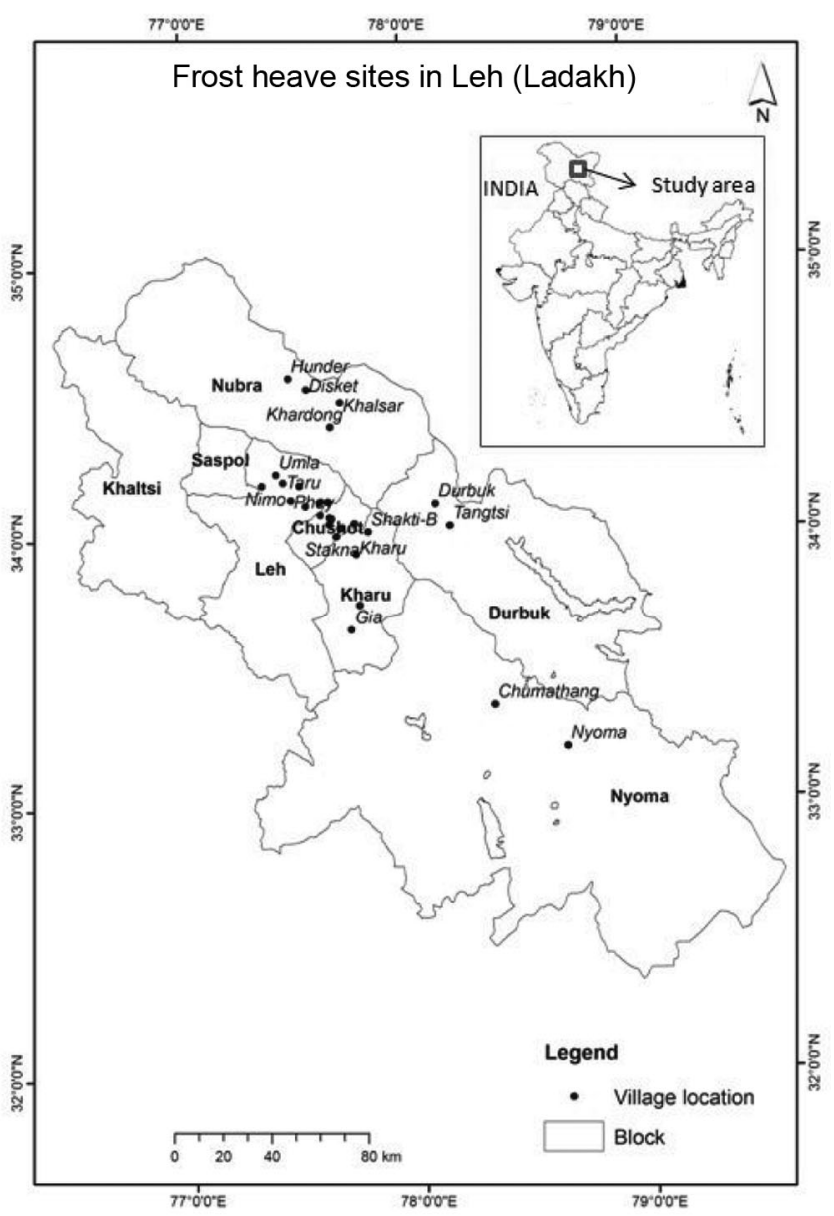

Figure 1. Location of surveyed sites (villages) in different blocks of the Leh-Ladakh region, India.

CURRENT SCIENCE, VOL. 119, NO. 5, 10 SEPTEMBER 2020 
RESEARCH ARTICLES

Table 1. Morphometry of frost heaves at different sites of Leh and Nubra region, India

\begin{tabular}{|c|c|c|c|c|c|c|c|c|c|}
\hline Site & $\begin{array}{l}\text { Frost heave } \\
\text { (FH) ID }\end{array}$ & $\begin{array}{l}\text { Latitude/longitude } \\
\text { and elevation (m) }\end{array}$ & Place, block & $\begin{array}{l}\text { Physiography/ } \\
\text { land-use }\end{array}$ & $\begin{array}{c}\text { Frost heave } \\
\text { area (ha) }\end{array}$ & $\begin{array}{l}\text { Length } \\
\text { (m) }\end{array}$ & $\begin{array}{l}\text { Width } \\
(\mathrm{m})\end{array}$ & $\begin{array}{l}\text { Height } \\
\text { (m) }\end{array}$ & $\begin{array}{c}\text { Type and } \\
\text { pattern frost } \\
\text { leave }\end{array}$ \\
\hline \multirow[t]{3}{*}{ I } & FH 1(a) & $77^{\circ} 36^{\prime} 58^{\prime \prime} \mathrm{E}$ & \multirow[t]{3}{*}{ Saboo } & \multirow{3}{*}{$\begin{array}{l}\text { Gently sloping land } \\
\text { interspersed with } \\
\text { narrow and } \\
\text { shallow stream } \\
\text { channels, } \\
\text { grasslands and } \\
\text { hot springs }\end{array}$} & \multirow[t]{3}{*}{0.70} & 6.10 & 3.23 & 0.77 & Massive \\
\hline & FH 1(b) & $34^{\circ} 07^{\prime} 38^{\prime \prime} \mathrm{N} ; 3435$ & & & & 4.57 & 1.88 & 0.46 & $\begin{array}{l}\text { Elongated and } \\
\text { jointed }\end{array}$ \\
\hline & FH 1(c) & & & & & 1.45 & 0.89 & 0.26 & Single \\
\hline \multirow[t]{3}{*}{ II } & FH 2(a) & $\begin{array}{l}77^{\circ} 44^{\prime} 22^{\prime \prime} \mathrm{E} \\
34^{\circ} 02^{\prime} 45^{\prime \prime} \mathrm{N} ; 3640\end{array}$ & \multirow[t]{3}{*}{ Stakmo } & \multirow{3}{*}{$\begin{array}{l}\text { Valley side } \\
\text { covering upper } \\
\text { part of stream }\end{array}$} & \multirow[t]{3}{*}{0.34} & 3.9 & 2.28 & 0.91 & Massive \\
\hline & FH 2(b) & Same spot & & & & 1.3 & 1.05 & 0.24 & Elongated \\
\hline & FH 2(c) & Same spot & & & & $0.1-0.68$ & $0.55-06$ & $0.19-0.23$ & $\begin{array}{l}\text { Flat collapsed } \\
\text { forms }\end{array}$ \\
\hline \multirow[t]{6}{*}{ III } & FH 3(a) & $\begin{array}{l}78^{\circ} 12^{\prime} 12.8^{\prime \prime} \mathrm{E} \\
34^{\circ} 01^{\prime} 60.7^{\prime \prime} \mathrm{N} ; 3997\end{array}$ & \multirow[t]{3}{*}{ Tangtse } & \multirow[t]{3}{*}{$\begin{array}{l}\text { Riverside, pasture } \\
\text { lands }\end{array}$} & \multirow[t]{3}{*}{7.16} & 2 & 1.3 & 1.2 & Elongated \\
\hline & FH 3(b) & Same location & & & & 1.25 & 0.83 & 0.43 & Elongated \\
\hline & FH 3(c) & Same location & & & & 0.52 & 0.46 & 0.18 & $\begin{array}{l}\text { Single and } \\
\text { round }\end{array}$ \\
\hline & FH 3(d) & $\begin{array}{l}78^{\circ} 12^{\prime} 22^{\prime \prime} \mathrm{E} \\
34^{\circ} 01^{\prime} 55^{\prime \prime} \mathrm{N} ; 3989\end{array}$ & $\begin{array}{l}\text { Tang tse to } \\
\text { Durbuk }\end{array}$ & Saline pastoral land & 2.0 & 8 & 0.5 & 0.45 & Elongated \\
\hline & FH 3(e) & $\begin{array}{l}77^{\circ} 12.826^{\prime} \mathrm{E} \\
34^{\circ} 02.268^{\prime} \mathrm{N} ; 4016\end{array}$ & Durbuk & $\begin{array}{l}\text { Riverbed/ } \\
\text { pasturelands }\end{array}$ & 4.2 & 1.5 & 0.90 & 1.5 & $\begin{array}{l}\text { Elongated and } \\
\text { massive }\end{array}$ \\
\hline & FH 3(f) & & Tang tse & & & 1.8 & 0.9 & 0.36 & Elongated \\
\hline \multirow[t]{2}{*}{ IV } & FH 4(a) & $\begin{array}{l}77^{\circ} 49^{\prime} 01^{\prime \prime} \mathrm{E}, \\
33^{\circ} 59^{\prime} 53^{\prime \prime} \mathrm{N} ; 3817\end{array}$ & \multirow[t]{2}{*}{ Sakti } & \multirow{2}{*}{$\begin{array}{l}\text { Rocky and boulder } \\
\text { filled swampy } \\
\text { land }\end{array}$} & \multirow[t]{2}{*}{0.95} & 7.30 & 0.80 & 0.36 & $\begin{array}{l}\text { Elongated, } \\
\text { vegetated }\end{array}$ \\
\hline & $\mathrm{FH} \mathrm{4(b)}$ & $\begin{array}{l}77^{\circ} 56.447^{\prime} \mathrm{E}, \\
34^{\circ} 04.632^{\prime} \mathrm{N} ; 3817\end{array}$ & & & & 3.5 & 1.10 & 0.40 & $\begin{array}{l}\text { Elongated, } \\
\text { nonlinear/ } \\
\text { serpentine }\end{array}$ \\
\hline V & FH 5 & $\begin{array}{l}77^{\circ} 29^{\prime} 55.31^{\prime \prime} \mathrm{E} \\
34^{\circ} 35.31^{\prime} \mathrm{N} ; 3133\end{array}$ & $\begin{array}{l}\text { Nubra, } \\
\text { Hunder }\end{array}$ & $\begin{array}{l}\text { Swampy land at the } \\
\text { base of rocky } \\
\text { mountains }\end{array}$ & 5 & 0.80 & 0.70 & 0.36 & $\begin{array}{c}\text { Smaller heaves } \\
\text { in a colony } \\
\text { of formation }\end{array}$ \\
\hline VI & FH 6 & $\begin{array}{l}77^{\circ} 57.318^{\prime} \mathrm{E} \\
33^{\circ} 19.430^{\prime} \mathrm{N} ; 4594\end{array}$ & Giya & $\begin{array}{l}\text { Wetland, saline land } \\
\text { and a salt lake }\end{array}$ & 11.9 & 1.5 & 0.75 & 0.28 & \\
\hline
\end{tabular}

Table 2. Soil properties of frost heave-affected areas

\begin{tabular}{lcccl}
\hline Soil sample location & $\mathrm{pH}$ & $\begin{array}{c}\text { Electrical } \\
\text { conductivity }\left(\mathrm{dS} \mathrm{m}^{-1}\right)\end{array}$ & $\begin{array}{c}\text { Organic } \\
\text { carbon (\%) }\end{array}$ & $\begin{array}{c}\text { Remarks } \\
\text { (severity) }\end{array}$ \\
\hline Saboo & 9.02 & 0.73 & 0.015 & Sodic \\
Tangtse & 8.19 & 0.14 & 3.18 & Normal \\
Sakti & 8.34 & $1.27-4.83$ & 1.33 & Slightly sodic \\
Tso Kar & & 57.2 & & Saline \\
Stakmo & 7.91 & 0.04 & 1.17 & Slightly sodic \\
Chushot & 7.79 & 0.76 & 0.10 & Slightly sodic \\
Thiksey & 8.4 & 0.31 & 0.97 & Sodic \\
\hline
\end{tabular}

intensity of wind erosion. Low organic matter and low nutrients are due to sparse vegetation cover. Salyx and Juniperus with stands of Artemisia, Lonicera and Hippophae species are the major constituents of tree and vegetation cover. Soils associated with evaporites of salt lake at Tso Kar indicate very high salinity (EC
$57.2 \mathrm{dS} \mathrm{m}^{-1}$ ) (Table 2). Deep soils $(5-15 \mathrm{~cm})$ having grass cover on the surface of frost heaves are found to be non-saline. At lower altitudes in the valleys of Sakti and Tangtse village, soils are slightly sodic. Percentage of organic carbon is higher in soils at Tangtse, Stakmo and Sakti. 
Table 3. Physical properties of soils at the frost heave formation sites

\begin{tabular}{|c|c|c|c|c|c|}
\hline $\begin{array}{l}\text { Sample location } \\
\text { (village) }\end{array}$ & Site characteristics & Clay $(\%)$ & Silt $(\%)$ & $\begin{array}{c}\text { Coarse sand } \\
(\%)\end{array}$ & $\begin{array}{c}\text { Fine sand } \\
(\%)\end{array}$ \\
\hline Tso Kar & Grassland around salt lake & 9.30 & 16.53 & 20.42 & 53.75 \\
\hline Tso Kar & Frost heave site, riverbank & 10.24 & 6.15 & 17.40 & 66.21 \\
\hline Tang La & Weathered rock sediments on hill slope & 5.15 & 20.58 & 34.12 & 40.15 \\
\hline Giya & Frost heave (topsoil), $3 \mathrm{~km}$ upstream of salt lake & 3.07 & 20.45 & 13.98 & 62.50 \\
\hline Debring & Extensive grassland, $8 \mathrm{~km}$ upstream of Giya & 5.19 & 5.19 & 33.16 & 56.46 \\
\hline Tangtse & Grassland & 7.22 & 1.03 & 49.98 & 41.77 \\
\hline Sakti & Frost heave site, topsoil & 4.13 & 11.37 & 22.65 & 61.85 \\
\hline Sakti & Frost heave (at $10 \mathrm{~cm} \mathrm{depth)}$ & 6.12 & 12.24 & 26.29 & 55.35 \\
\hline
\end{tabular}

Table 4. Typical vegetation association on frost heaves

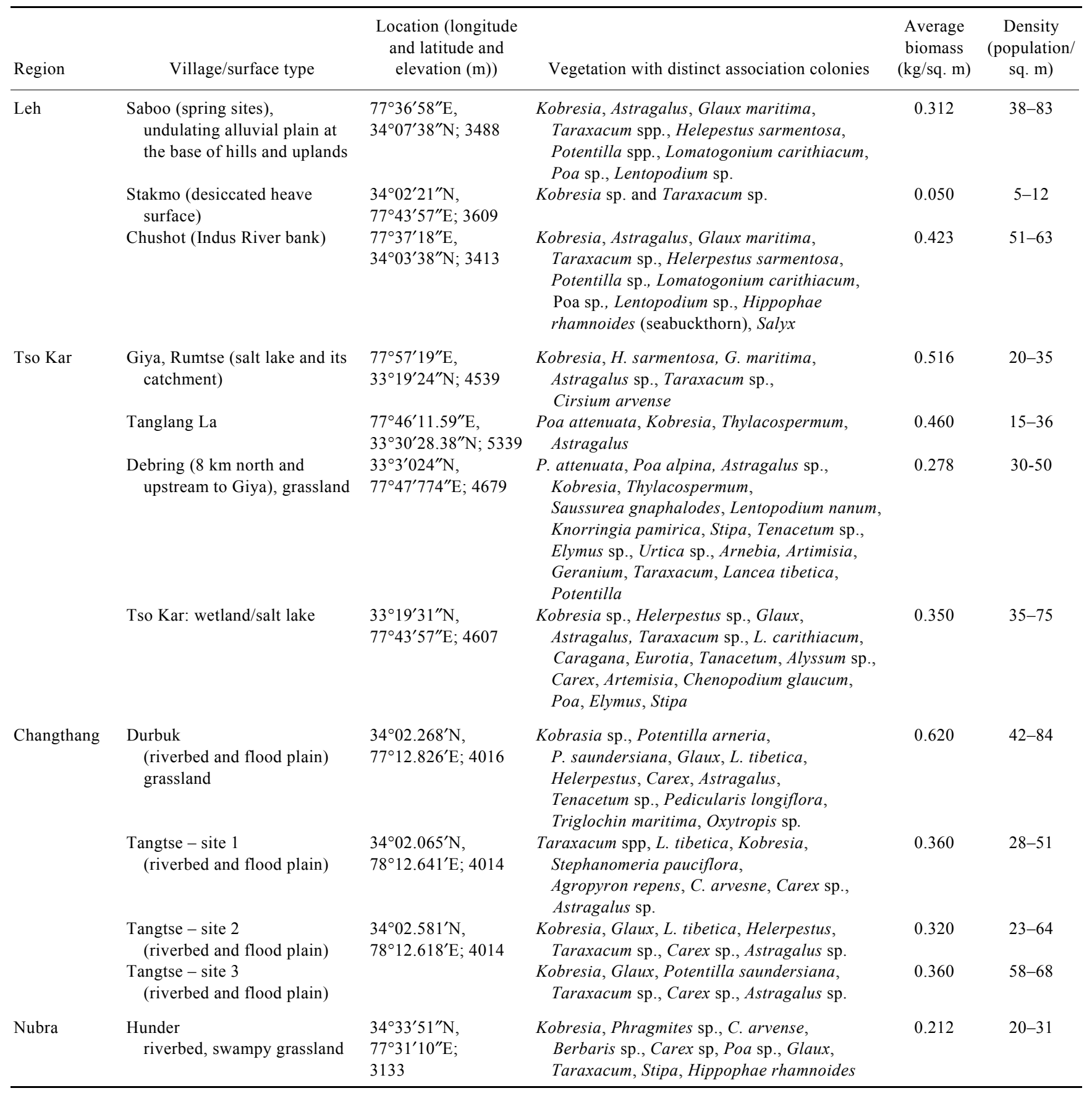




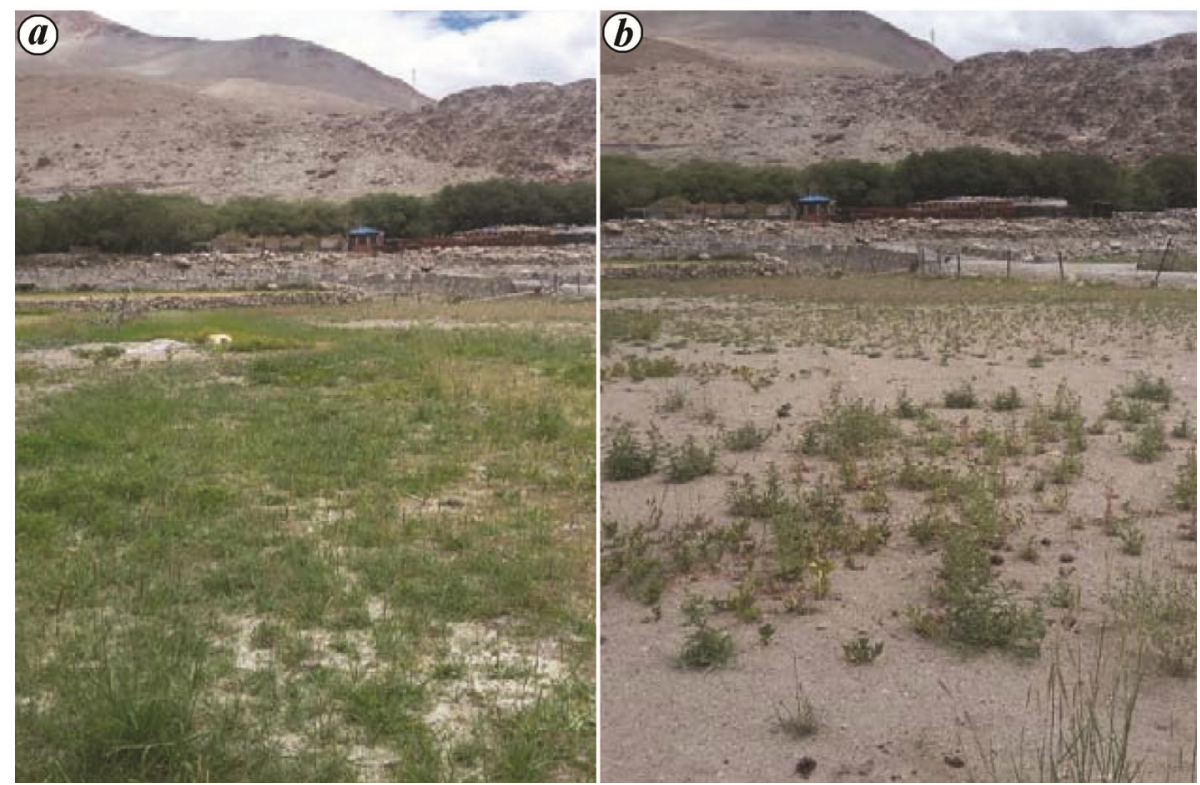

Figure 2. $\boldsymbol{a}$, Area showing significant presence of native species without Cirsium, 30-60 plants per sq. $\mathrm{m}$ area. $\boldsymbol{b}$, Presence of Cirsium and allelopathic effect showing displacement of native species.

\section{Vegetation composition and biomass accumulation}

Table 4 provides details of vegetation (grasses). In loweraltitude areas near Saboo, clusters of Kobresia, Astragalus, Glaux spp, Taraxacum spp and Cirsium arvense are noticed while at higher altitudes near Hunder in Nubra valley, Kobresia, Phragmites spp, C. arvense and Carex spp. occur. In Tangtse valley of Changthang region, vegetation is mostly dominated by tiny rossette, sedges and other cohesive groups of vegetation such as Kobresia, Lentopodium, Astragalus, Potentilla, Helerpestus sp., Triglochin sp., Puccinellia sp., Lancea tibetica and Glaux maritima. Here $C$. arvense is found to replace the native vegetation in frost-heave lands and has allowed Carex species, which can deplete and change the pasture ecology. In Tso Kar saline areas, Kobresia, Glaux, Astragalus are the major species along with weedy species of C. arvense and Carex. The dry and green biomass on heaves range from 0.05 to $0.62 \mathrm{~kg} \mathrm{sq} . \mathrm{m}$ at Saboo, Tangtse, Tso Kar and Nubra areas. In all pastures, feeding pressure posed by nomadic livestock and other wild animals has impacted the plant mantle significantlyabout $30 \%$. C. arvense, an invasive weed has been observed to capture the frost-leave mounts, thereby reducing the endemic flora (Figure $2 a$ and $b$ ).

\section{Description of frost-heaves}

\section{Occurrences and morphological variability}

In the study area, frost-heave lands occur under three topographic situations: uplands (on the hill slopes and pediments), wetlands (plains) and lower plains (riverbanks). Morphological patterns of the heave surfaces are shown in Figure 3. Based on the measurements of physical dimensions (length, width and height) of individual or groups of frost heaves, they have been categorized into: very big heaves ( $>4 \mathrm{~m}$ long), big (2-4 $\mathrm{m}$ long) and small heaves $(<1 \mathrm{~m}$ long). Further, the heaves have been categorized on the basis of their shapes and patterns: (a) single, small and rounded; (b) joined and elongated, linear/serpentine and (c) coalesced and massive (Figure $3 a-f$ ). Site-based detailed account of their status and morphometry is discussed below.

Site I (Saboo village): This is located $5 \mathrm{~km} \mathrm{SE}$ of Leh city at an average elevation of $3444 \mathrm{~m}$ amsl. Here, frost heaves occur in a section of low, gentle-sloping upland at the foot of barren hills. The surface is dissected by a number of run-off channels, and heaves occur along the banks of streams extending up to $500 \mathrm{~m}$ on both sides. Close to the streams the heaves are single- and roundshaped and about $20-40 \mathrm{~m}$ away from stream banks, the heaves are generally elongated and dry. The clustered and massive forms are $7.3 \mathrm{~m}$ long, $0.80 \mathrm{~m}$ wide and $0.46 \mathrm{~m}$ high, while small and single heaves are $0.35 \mathrm{~m}$ long, $0.3 \mathrm{~m}$ wide and $0.10 \mathrm{~m}$ high. The site has good grass cover. Soil profile of heaved land shows upper layer of sand (at $3-5 \mathrm{~cm}$ depth) followed by clay soil $(12-$ $15 \mathrm{~cm}$ depth) with root zones of plant species (Figure $4 a$ ). A small number of hot springs are present in this area, which help lands avail water and moisture for most part of the year. Locally, these sites are known as 'Chutsen'. 


\section{RESEARCH ARTICLES}
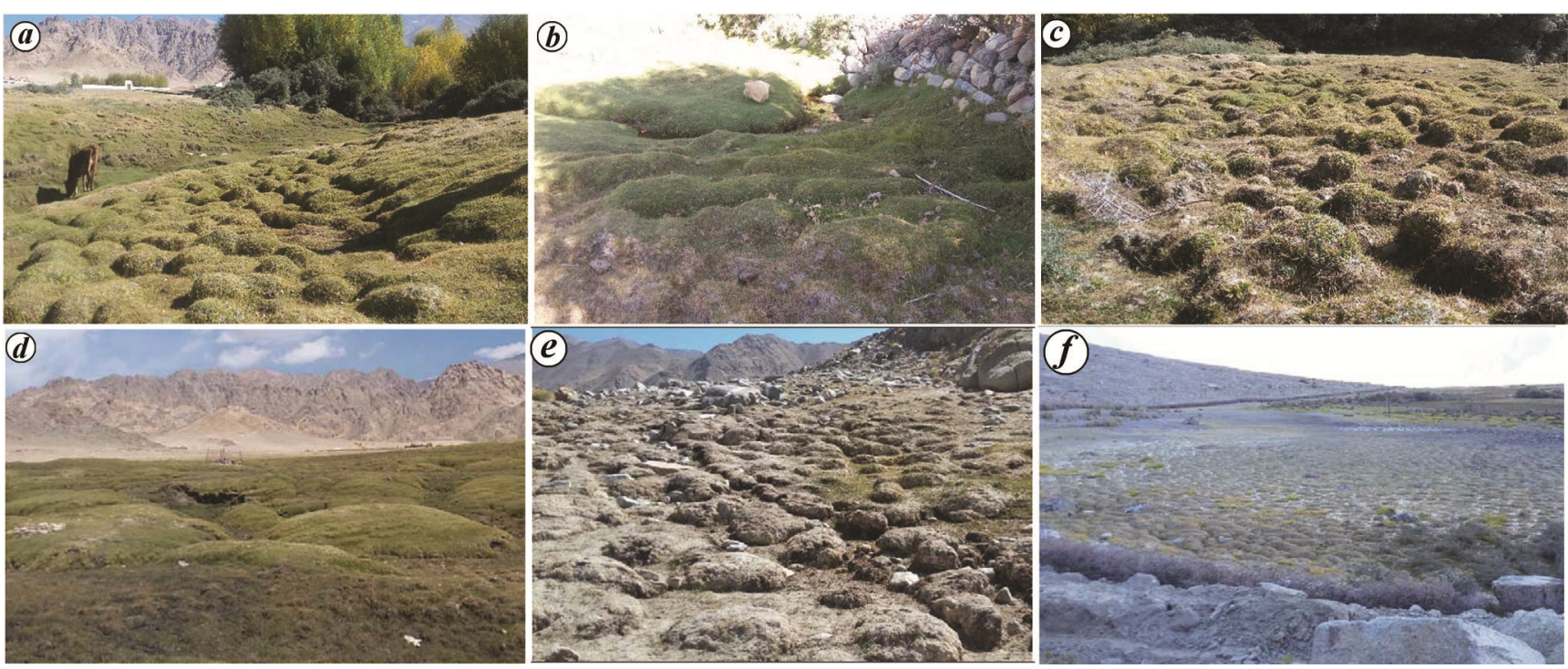

Figure 3. $\boldsymbol{a}$, Typical frost heave terrain at Saboo. $\boldsymbol{b}$, Elongated form of heaves at Saboo. $\boldsymbol{c}$, Group of single and oval-shaped heaves at Saboo. $\boldsymbol{d}$, Compact heaves and older formations with drainage channels at Saboo. $\boldsymbol{e}$, Heaving along with stones and boulders at Stakmo. $\boldsymbol{f}$, A colony of smaller frost heaves under submerged condition at Hunder in Nubra valley.
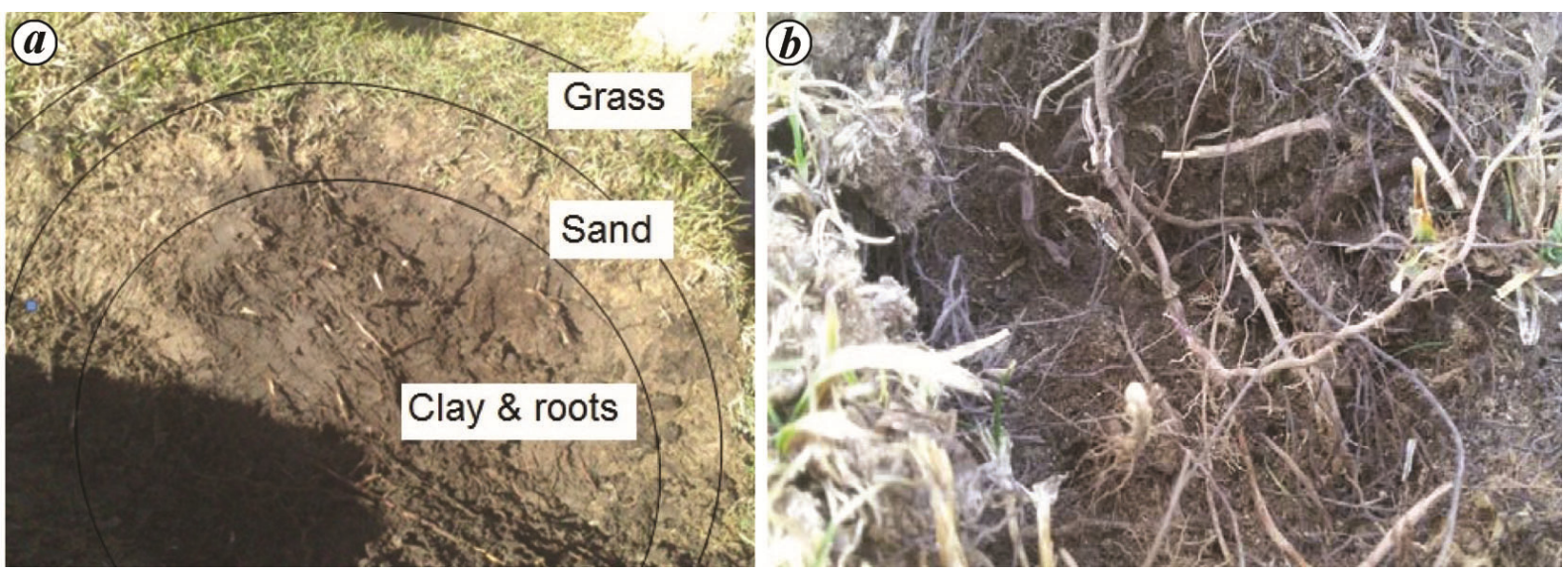

Figure 4. $\boldsymbol{a}$, A cross-section of a frost heave at Saboo: grass species $(4-6 \mathrm{~cm})$, sand $(3-5 \mathrm{~cm})$, clay (dark tone; $13-15 \mathrm{~cm})$ and root exposures. $\boldsymbol{b}$, Dry roots of grass species in a desiccated frost heave.

Site II (Stakmo village): This is situated $25 \mathrm{~km}$ away from Leh town, where the heaves are much bigger in size and massive. Rocks/stone fragments can be seen on the subsurface of the heaves. Most of the heaves, are dry, desiccated and deformed. The bigger/massive ones show assemblage of many smaller heaves (Figure $5 a$ ) and resemble a single compact formation. The round and convex heaves are ruptured, collapsed and eroded to form flat, powdery or amorphous sediments (Figure $5 b-d$ ). Local people use these dried plant materials as fuel.

Site III (Tangtse-Changthang in Durbuk block): These extensive grasslands are located about $71 \mathrm{~km}$ east of Leh on Pangong Tso road. These lands are high altitude valleys, interspersed with the stream network of River
Harong which is a tributary of the Indus River. The grasslands are undulating with a large number of low and isolated heaves. At one location, there were $4-5$ heave site clusters, each having 300-500 single and smaller heaves. People of Changthang region are nomadic pastoralists, locally called 'Changpas'. Their livelihood is mainly based on livestock, particularly Pashmina goat rearing. According to the 2012 animal census for Leh-Ladakh region, Durbuk (administrative block) has about 8000 animals with a livestock density of 9 per sq. $\mathrm{km}$. These livestock numbers are high for a region where there is limited arable land for grassland development. The Changpas usually move short distances and follow established routes and often, their place of stay is the same. Therefore, they are more conservative to the upkeep of 

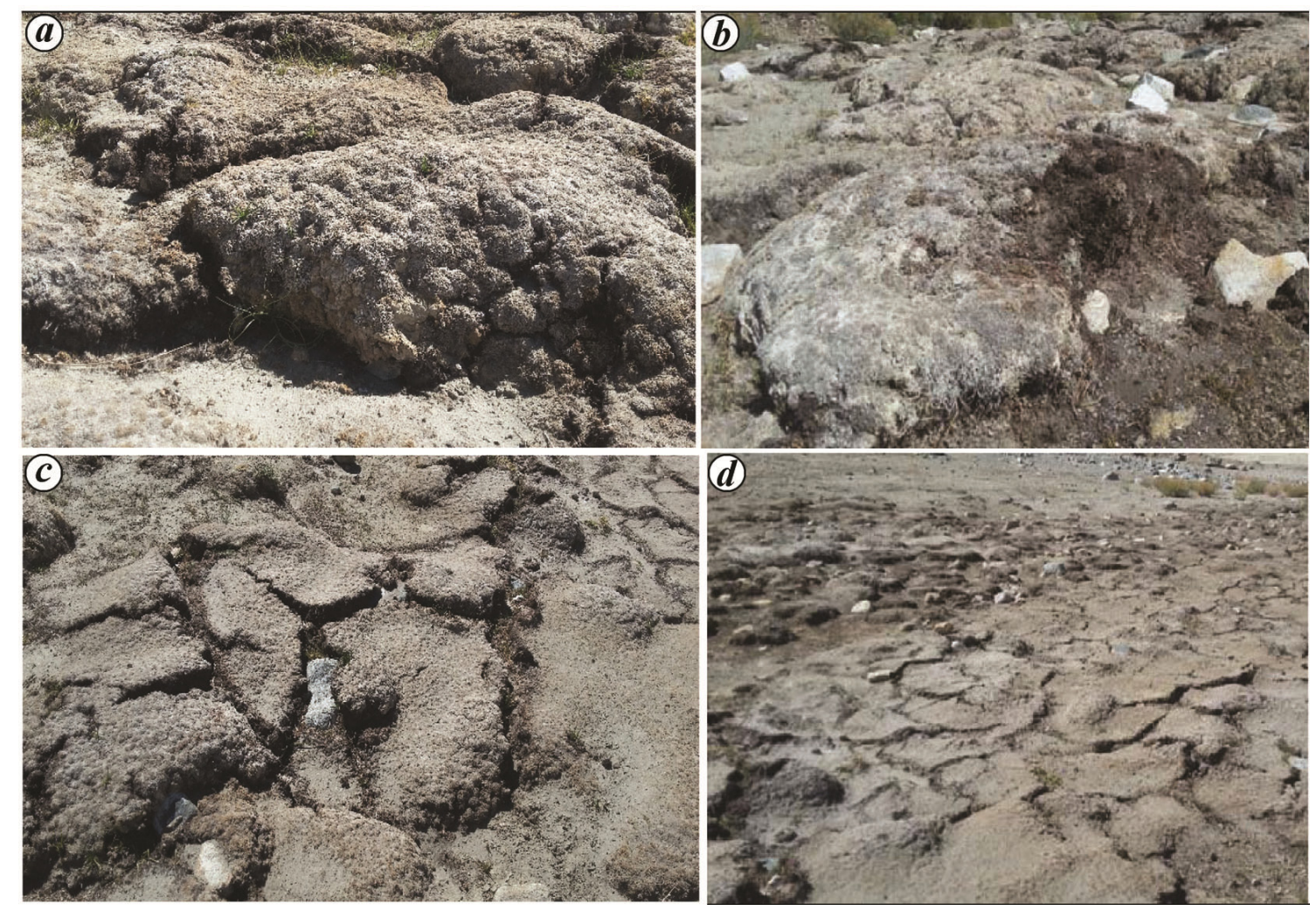

Figure 5. a, Complex pattern, many-in-one heave formation at Stakmo. $\boldsymbol{b}$, Degraded/deformed frost heaves at Stakmo. $\boldsymbol{c}$, Desiccated heaves, development of cracks, collapsed walls and flattened lobes at Stakmo. $\boldsymbol{d}$, Final collapsed and flattend forms of frost heaves at Stakmo.

grasslands. In Changthang pastureland, there are incidences of weeds and non-palatable species invading the tiny rosette, sedges and other cohesive group of vegetation such as Kobresia spp, Carex, Leontopodium pusillum, Astragalus strictus. Triglochin spp, Puccinellia spp and G. maritima. Although these pastures are dominated by one of the smallest Cyperaceae endemic plants, growing not taller than $2-3 \mathrm{~cm}$ high covering more than $90 \%$ of the area, the rest of the vegetation consists of $8-10$ mostly tiny rosette species (e.g. Thalictrum alpinum, Potentilla saundersiana, Aster flaccidus, Primula walshii and Pedicularis spp) $C$. arvense, an invasive weed has started growing in this site and it can reduce the local vegetation by $60 \%$.

Site IV (Giya-Rumtse-Debring-Miru-Tso Kar): This is located at an altitude of $4640 \mathrm{~m}$ amsl on the Leh-Manali highway, where several frost heave surfaces are noticed. Lake Tso Kar is a landmark tourist site situated $153 \mathrm{~km}$ southeast of Leh town. It is a small lake ( 9 sq. $\mathrm{km}$ area), connected to an inlet stream in a part of the valley situated in the Rupshu Plateau and another valley in the southern part of Ladakh ${ }^{12}$. Until a few years ago, the local Changpa nomads used to export salt from this lake to Tibet. The river valley is a grazing land on which the local nomads camp. Here 12-13 small and rounded heaves are found in a $5 \mathrm{~m} \times 5 \mathrm{~m}$ grid. Grasses like Kobresia and Helerpestus dominate at Giya and Rumtse, while Lentopodium nanum, Knorringia pamirica and Stipa are abundant uphill at Debring. Biomass of grass species has also been measured (Table 4).

Site V (Sakti village in Kharu block of Leh district): This is one of the bigger settlements in this region. Physiographically, the village sits on a very narrow (width $100-1500 \mathrm{~m})$ and elongated (13 km long) valley aligned in a NE-SW direction. Much of the frost heave lands are noticed in a traverse in Kharu-Sakti-Jingral-DurbukTang tse sector mainly occurring on flat and swampy depressions. Morphologically, these heaves are big, elongated and oval-shaped, and many of them are joined to each other forming a network pattern. As at Saboo, the frost-heave surfaces are covered with a luxuriant growth of green grass but at the periphery of the heaves, there are patches of white soil crusts. Looking at the large number of livestock ( $\sim 7500$ according to the 2012 livestock census) and a density of 8.8 per sq. km, grasslands are important. Uphill at Tangtse, grasslands occur extensively on the riverside; Kobresia spp is dominant. Table 4 provides a detail of the species extant in this region. 
Site VI (Diskit-Hunder area in Nubra valley): Diskit and Hunder are two of the important tourist towns in Nubra region of Ladakh. Diskit is situated about $118 \mathrm{~km}$ from Leh and $11 \mathrm{~km}$ from Hunder. Two major rivers of the region, viz. Nubra and Shyok joined at this site. Diskit is situated on the banks of River Shyok, known for a landscape with unique assemblages of crescent-shaped sand dunes and dunes. Frost heaves at Diskit occur within a large swampy depression; most are them are single and small in size. Kobresia, Phragmites spp, C. arvense and Carex spp, occur in good proportion on these frost heaves.

\section{Frost heaving and land degradation}

Frost heaving is a process of swelling and shrinking of land/soil causing deformation of land with various shapes and sizes. During winter, these lands can be completely eroded and shift due to mass movement promoting soil erosion. In the area where there is stagnant water or permanent water flow, frost heaves have good vegetation and grass cover. But those occurring away from water source are dry, desiccated and show eroded morphology. At Saboo and Sakti, most of the heaves are linear and elongated types. The soils are very deep consisting of sediments transported by run-off of snowmelt water. At Stakmo, two types of features have been observed: (a) instances of boulders and rocks being heaved to the ground surface (Figure $3 e$ ), which can be the result of freezing and thawing, and (b) complex pattern which demonstrates an example when smaller heaves have expanded and gradually joined together to form compact and massive structures (Figure $3 d$ ). In contrast, some degraded heaves are also noticed (Figure $5 b-d$ ). Such features indicate impact of desiccation when a compact, rounded or oval heave mound gradually flattens. Subsequently, heaves develop cracks and get eroded.

Grasses growing on such surfaces dry up and indicate gradual dying of the plant sections above and below the ground and decay of root litter that expands the surface cracks. Frost heaving accompanied with invasion of C. arvense, soil salinity and feeding pressure by livestock are the major processes identified for pasture degradation. In Changthang grasslands, the survey showed few invasive and exotic weeds like $C$. arvense. Such species are known to survive, establish themselves under harsh conditions and invade the heaves and start affecting the native vegetation due to allelopathy. This may be one of the reasons why interspaces between two heaves are devoid of any vegetation or remain barren at several locations, as in Tso Kar, Stakmo and Giya.

Since all these sites are grazing lands, continuous and regular grazing by nomadic livestock and other wild animals reduces the grass cover enabling the invasive species like $C$. arvense to dominate the vegetation cover.
Frost heaves require a frost susceptible soil, continuous supply of water from the water table and freezing temperature penetrating the soil. Studies have indicated that not all soils are susceptible to frost heaving. It is found more in soils that facilitate capillary flow. Thus frost-susceptible soils are fine-textured, with silt, loam and very fine sand $^{13}$. Perkins ${ }^{14}$ reported that frost also helps sort the sediments in the ground. We observed similar conditions in the surveyed sites. For example, at Saboo the outer portion of heaves contained finer sediments and coarse particles remained clinging to the mantle or inner core. Under wetland conditions, frost-heave surfaces act as excellent grazing lands; but under dry and water-deficit conditions, the topsoil breaks and gradually disintegrates to amorphous or powdery form and heaves become devoid of any grass or vegetation.

\section{Conclusion}

In cold arid regions of Leh-Ladakh and Nubra valleys, frost heaves occur along the river banks, in the valleys and near water points. Based on their shape, size and morphological pattern, frost heaves can be classified into simple and complex types. Recently formed frost heaves are single and small, while older ones are compact, elongated and massive with distinct soil profiles. The patterns vary from single to network type. Soil-water content, flowing water in the rivers and stones are important factors for variability in the morphology and degradation of frost-heave lands. In dry condition, the morphology and soils of frost-heave features show degradation like dryness, shrinkage, erosion, disintegration and collapsing of forms, leaving behind amorphous or powdery sediments and dried vegetation. Such processes have been found to affect the status of vegetation growing on frost heaves. In this study we also found invasion of weeds like $C$. arvense on these heaves which has not only thrived well, but has replaced the native vegetation and allowed Carex species to grow, which is known to degrade and deplete the palatable plants or grass species and affect pasture ecology. The present study can serve as a basic inventory of frost heaves and their morphological patterns in the Leh-Ladakh region. It also shows how pasturelands of the region are undergoing degradation due to frost-heaving processes.

1. Willams, P. J., Frost heave. In Encyclopaedia of Geomorphologists, V-1 (A-I) (ed. Goudie, A. S.), Tailor \& Francis e-library, Routledge, 2006, pp. 415-416.

2. French, H., The Periglacial Environment, Longman, Harlow, 1996, p. 341, 2nd edn.

3. Pissart, A., Palsas, lithalsas and remnants of these periglacial mounds, a progress report. Prog. Phys. Geogr., 2002, 26(4), 605621.

4. Mackay, J. R., Pingo growth and collapse, Tuktoyaktuk Peninsula Area, Western Arctic Coast, Canada: a long-term field study. Geograph. Phys. Quatern., 1998, 52(3), 271-323. 


\section{RESEARCH ARTICLES}

5. Beskow, G., Soil freezing and frost heave with special application to roads and railroads. C. No. 375, Year Book no. 3 (Trans. Osterberg, J. O. Sweden, Geological Society, Technological Institute, Northwestern University), 1935.

6. Rempel, A. W., Frost heave. J. Glaciol., 2010, 56, 1122-1128.

7. IGFRI, Grasslands of Himachal Pradesh, IGFRI, Jhansi, 2009, p. 65 .

8. SAC, Land degradation atlas of India. Space Application Centre, Indian Space Research Organization, Ahmedabad, India, 2007, p. 74.

9. Kumar, A., Srivastava, P. and Meena, N. K., Late Pleistocene Aeolian activity in the cold desert of Ladakh: a record from sand ramps. Quatern Int., 2016; http:dx.doi.org/10.1016/j.quaint. 2016.04.006.

10. Bharti, V. K. et al., Modern dairy farming in cold arid region of Leh-Ladakh: innovatives in Agro-Animal Technologies (eds Srivastava, R. B. and Selvamurthy, W. S.), Serial Publishing House, Delhi, 2011, pp. 193-203.

11. Charan, G., Bharti, V. K., Jadhav, S. E., Kumar, S., Angchok, D. Acharya, S., Kumar, P. and Srivastava, R. B., Altitudinal variations in carbon storage and distribution patterns in cold desert high altitude region of India. Afr. J. Agric. Res, 2012, 7, 6313-6319.
12. https://en.wikipedia.org/wiki/Tso_Kar

13. Manz, L., Frost heave. Geo. News, 2011, 18-24.

14. Perkins, S., Patterns from nowhere; natural forces bring order to untouched ground. Sci. News, 2003, 163(20), 314-316; doi: $10.2307 / 4014632$.

15. Taber, S., Frost heaving. J. Geo., 1929, XXXVII, 428-461.

ACKNOWLEDGEMENTS. We thank the Director, ICAR-Central Arid Zone Research Institute (CAZRI), Jodhpur; Head, Division of Natural Resources, Jodhpur, and Head, CAZRI-Regional Research Station (RRS), Leh for providing the necessary facilities to carry out field work in the Leh-Ladakh region. We also thank the Department of Science and Technology for financial support through the ICARNMSHE-Task Force 6 and the staff of ICAR-CAZRI RRS, Leh for help during field work.

Received 15 October 2019; revised accepted 1 June 2020

doi: $10.18520 / \mathrm{cs} / \mathrm{v} 119 / \mathrm{i} 5 / 799-807$ 